$$
\text { Cosf- } 9409282-1
$$

WSRC-MS-94-013

\title{
TECHNETIUM-99, IODINE-129 AND TRITIUM IN THE WATERS OF THE SAVANNAH RIVER SITE()
}

\author{
D.M. Beals and D.W. Hayes
}

\section{DISCLAIMER}

\begin{abstract}
This report was prepared as an account of work sponsored by an agency of the United States Government. Neither the United States Government nor any agency thereof, nor any of their employees, makes any warranty, express or implied, or assumes any legal liability or responsibility for the accuracy, completeness, or usefulness of any information, apparatus, product, or process disclosed, or represents that its use would not infringe privately owned rights. Reference herein to any specific commercial product, process, or service by trade name, trademark, manufacturer, or otherwise does not necessarily constitute or imply its endorsement, recommendation, or favoring by the United States Government or any agency thereof. The views and opinions of authors expressed herein do not necessarily state or reflect those of the United States Government or any agency thereof.
\end{abstract}

\section{Westinghouse Savannah River Company Savannah River Site Aiken, South Carolina 29808}

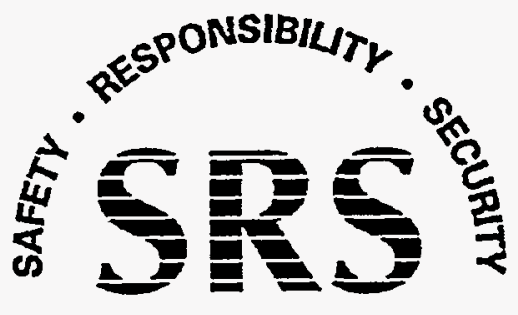

SAVANNAH RIVER SITE

This Document produced for the U.S. Department of Energy under Contract No. DE-AC09-89SR18035

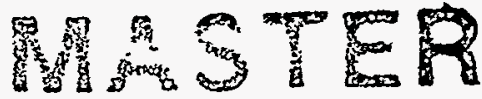




\section{DISCLAIMER}

Portions of this document may be illegible in electronic image products. Images are produced from the best available original document. 
This report was prepared by the Westinghouse Savannah River Company (WSRC) for the United States Department of Energy under Contract No. DE-AC09-89SR18035 and is an account of work performed under that contract. Neither the United States Department of Energy, nor WSRC, nor any of their employees make any warranty, expressed or implied, nor assume any legal liability or responsibility for the accuracy, completeness, or usefulness, of any information, apparatus, or product or process disclosed herein or represents that its use will not infringe privately owned rights. Reference herein to any specific commercial product, process, or service by trademark, name, manufacturer, or otherwise does not necessarily constitute or imply endorsement, recommendation, or favoring of the same by WSRC or by the United States Government or any agency thereof. The views and opinions of the authors expressed herein do not necessarily state or reflect those of the U.S. Government or any agency thereof.

This report has been reproduced directly from the best available copy

\section{Available to DOE and DOE Contractors from the \\ Office of Scientific and Technical Information,}

$$
\text { P..O. Box 62, }
$$

Oak Ridge TN 37831;

Prices available from

(615) $576-8401$

FTS 626-8401

Available to the public from the National Technical Information Service,

U.S. Department of Commerce

5285 Port Royal Road

Springfield VA 22161

Published in cooperation with the Management Information Services Publications Group.
Editor: Henry A. Hancock, Jr.




\title{
Technetium-99, Iodine-129 and Tritium in the Waters of the Savannah River Site
}

\author{
D.M. Beals and D.W. Hayes \\ Westinghouse Savannah River Company \\ Aiken, South Carolina, 29808 USA
}

\begin{abstract}
Surface water samples were collected from streams on and around the Savannah River Site, (SRS) to assess current ${ }^{3} \mathrm{H},{ }^{99} \mathrm{Tc}$, and ${ }^{129} \mathrm{I}$ concentrations in the water. The SRS is a nuclear facility operated by Westinghouse Savannah River Company for the US Department of Energy. Water quality parameters were measured at the time of collection using field portable instrumentation. The tritium activity was determined by liquid scintillation spectrometry. The isotopes, ${ }^{99} \mathrm{Tc}$ and ${ }^{129} \mathrm{I}$, were determined by isotope dilution/inductively coupled plasmamass spectrometry [1,2].
\end{abstract}

Elevated activities of ${ }^{3} \mathrm{H},{ }^{99} \mathrm{Tc}$, and ${ }^{129} \mathrm{I}$ were found in some surface streams of the SRS, principally due to migration of ground water from beneath old seepage basins, however the levels in the waters leaving the SRS are well below any regulatory guidelines.

\section{Introduction}

The Savannah River Site, located along the Savannah River in western South Carolina (Figure 1) was built and began production of nuclear materials in the 1950's. The primary mission of the SRS was to produce tritium and plutonium for the national defense program. However, the primary mission of the site at this time is environmental restoration and remediation. All reactor facilities are either shut down or placed in standby status. During the years of operation low levels of radioactive elements were released to the atmosphere and surface water, including seepage basins, of the SRS. These radioactive elements included uranium, plutonium and tritium [3], as well as the waste products ${ }^{14} \mathrm{C},{ }^{89,90} \mathrm{Sr},{ }^{99} \mathrm{Tc}$ [4], ${ }^{129} \mathrm{I}^{-}$ $[5],{ }^{134 / 137} \mathrm{Cs}$, and others.

To ensure the safety of the site workers, surrounding communities and downstream water supplies, the levels of radionuclides discharged from the SRS have been continuously monitored. Technetium exists as the very mobile $\mathrm{TcO}_{4}{ }^{-}$ion in oxidizing environments [6] and is known to concentrate in the thyroid and GI tract[7]. Iodine may exist as the reduced $\mathrm{I}^{-}$or the oxidized $\mathrm{IO}_{3}{ }^{-}$and concentrates in the thyroid of mammals. Due to the low specific activity of ${ }^{99} \mathrm{Tc}$ and ${ }^{129} \mathrm{I}$, (half lives of $2.12 \times 10^{5}$ and $1.57 \times 10^{7}$ years, respectively) they have been difficult to monitor in the surface waters of the SRS. The Savannah River Technology Center, (SRTC) at the SRS has recently developed simplified procedures to measure ${ }^{99} \mathrm{Tc}$ and ${ }^{129} \mathrm{I}$ in 
aqueous samples by isotope dilution/inductively coupled plasma-mass spectrometry, (ID/ICPMS) $[1,2]$.

In this study, the current concentration of ${ }^{3} \mathrm{H},{ }^{99} \mathrm{Tc}$ and ${ }^{129} \mathrm{I}$ was examined in the surface waters of the SRS to assess the impact of the SRS releases on the environment. This, is the largest data set compiled on ${ }^{99} \mathrm{Tc}$ and ${ }^{129} \mathrm{I}$ activities in the surface waters of the SRS. Grab samples were collected during winter, (high flow) and summer, (low flow) over a period of 2 to 3 years. The ${ }^{3} \mathrm{H}$ activity was determined by liquid scintillation spectrometry, and the ${ }^{99} \mathrm{Tc}$ and ${ }^{129} \mathrm{I}$ were determined by $\mathrm{ID} / \mathrm{ICP}-\mathrm{MS}$.

Samples were collected from five different watersheds on the SRS and from one offsite creek, (Figure 2A and 2B). Hollow Creek was chosen as a control background watershed. It receives no discharge from the SRS. The Upper Three Runs, (U3R) watershed is the only SRS stream system to originate offsite. South Carolina state Highway 278 runs along the northern boundary of the SRS; Tyler Bridge Road, SRS Road 2.1, is also above site activities. Therefore both sampling locations, Highway 278 and Road 2.1, along U3R and Tinker Creek, should also serve as background sampling locations. Tinker Creek conjoins with U3R above SRS Road F. Crouch Branch receives a small amount of discharge from the $\mathrm{H}$ separation area seepage basins and from the Solid Waste Disposal Facility, (SWDF). It enters U3R below Road F and above the confluence of U3R and Tim's Branch. Tim's Branch drains Steed Pond which is known to have elevated concentrations of uranium in the sediment [8]. Sampling point \#5 on Tim's Branch is just prior to Tim's Branch entering U3R. The junction of U3R and Tim's Branch is at the SRS Road C crossing. Beginning in 1988, low level radioactive waste process water from the SRS was treated by the Effluent Treatment Facility, (ETF) prior to release rather than being discharged, (as previously done) directly to seepage basins. The ETF treatment process is not capable of removing ${ }^{3} \mathrm{H}$ and has a low decontamination factor for Tc. The discharge from the ETF enters U3R just below SRS Road C. The sampling points at Road A, (South Carolina state Highway 125) and at Box Landing Road are below the ETF and are the last samples collected prior to U3R entering the Savannah River.

From 1954-1988 the seepage basins, several of which were located near the $F$ and $H$ separation areas, were used for the disposal of wastewater containing low concentrations of chemicals and radionuclides. Radionuclides released to the seepage basins included ${ }^{3} \mathrm{H},{ }^{99} \mathrm{Tc}$ and ${ }^{129} \mathrm{I}$. The seepage basins were intended to delay the release of radionuclides offsite by adsorption on the clay layers beneath them and allowing time for radioactive decay. Use of the seepage basins was discontinued in 1988 when the ETF was brought on line. The seepage basins were capped and sealed in 1990 . Water beneath the F- and $\mathrm{H}$-area seepage basins migrates with the flow of the groundwater, eventually outcropping into Fourmile Branch, which drains to the Savannah River.

Fourmile Branch originates near the middle of the SRS. Road F crosses Fourmile Branch near its headwaters. The Road F and Road E-1 crossing of Fourmile Branch are above aqueous input from SRS activities. Migrating water from the $\mathrm{H}$ separation area seepage basins 
enters Fourmile Branch above Road C. Migrating water from the F separation area seepage basins enters Fourmile Branch below the Road $C$ crossing. While the $C$ reactor was operating, secondary cooling water from the reactor was discharged to Fourmile Branch above the A-7 sampling point. The Road A sampling point is the last sample collected prior to Fourmile Branch entering the Savannah River flood plain.

Pen Branch does not receive any SRS aqueous discharge prior to the Road B sampling point. Indian Grave Branch carried secondary cooling water from the $\mathrm{K}$ reactor , (a tritium production reactor now being shut down) to Pen Branch. Indian Grave currently receives migrating groundwater from below the $\mathrm{K}$ area seepage basin. The Road $\mathrm{A}$ sampling point of $\mathrm{Pen} B \mathrm{Branch}$ is below the confluence of Indian Grave with Pen Branch. Below this point, Pen Branch enters the Savannah River swamp. It mixes with Steel Creek just prior to entering the Savannah River.

The headwaters of Steel Creek are at the $P$ area reactor outfall. The first sample along Steel Creek was collected just below the outfall. During the years of reactor operation Steel Creek received effluent discharges from both $\mathrm{L}$ and $\mathrm{P}$ reactors. L Lake was built in 1985 to provide cooling for the $\mathrm{L}$ reactor thermal discharges by damming Steel Creek. At that same time, $\mathrm{P}$ reactor effluents were diverted to a seepage basin. Steel Creek currently receives migrating water from the P area seepage basin. Samples were also collected samples from Steel Creek in L Lake, at the top of the lake during one sampling period, and the outfall from the lake in all sampling periods, and at Road A, prior to mixing with Pen Branch and entering the Savannah River.

The last stream system sampled was the Lower Three Runs Creek system, (L3R). Par Pond was formed by damming $\mathrm{L} 3 \mathrm{R}$, and received cooling waters from $\mathrm{P}$ and $\mathrm{R}$ reactors. To improve cooling of reactor effluent, several other small ponds were constructed; Pond $B$ in the headwaters of L3R is the largest of these. Samples were collected in Pond B, Par Pond at the bubble up, (where new water is introduced to Par Pond from Pond C) and several locations below the Par Pond dam. At this time there are no direct discharges from SRS activities to the L3R system.

\section{Methods}

Sample Collection Samples were collected at the desired locations by dipping 2L polyethylene bottles below the surface of the water. The bottles had been rinsed with distilled and deionized water in a class 10,000 clean laboratory, (less than 10,000 particles per cubic foot) prior to use, and were rinsed with the sample water several times prior to filling and sealing the bottle. Field measurements of water quality were made at the time of sample collection. Samples were stored refrigerated at $4^{\circ} \mathrm{C}$ until analysis. All sample processing was performed in a class 10,000 clean laboratory; all analyses were performed on a aliquot of the sample from the same bottle. The ICP-MS is housed in a class 1000, (less than 1,000 particles per cubic foot) clean facility; the LSC in a class 10,000 facility. Reagent grade chemicals were 
used for the iodine determinations, ultrapure nitric acid, (Seastar Chemicals, Seattle WA, USA) was used for the technetium analyses.

\section{Instrumentation}

A Turner Spectrometry SOLA ICP-MS (now marketed by Finnigan MAT) was used for detection of ${ }^{99} \mathrm{Tc}$ and ${ }^{129} \mathrm{I}$. The SOLA is equipped with an automatic sampler and CETAC ultrasonic nebulizer for sample introduction. Tritium activities were determined on a Packard Tri-Carb 2050A liquid scintillation spectrometer with automatic quench correction. Water quality parameters were measured in the field at the time of sample collection using a Horiba U-10 water quality meter.

\section{Procedures}

Technetium-99 Typically a one litre sample is used for the ${ }^{99} \mathrm{Tc}$ determination. $\mathrm{A}^{97} \mathrm{Tc}$ tracer is added to the sample for isotope dilution analysis. The sample is heated in the presence of hydrogen peroxide to equilibrate the tracer with the sample and to ensure that the Tc is in the oxidized form. Technetium is then extracted from the sample using TEVA-Spec extraction chromatography material, (EIChroM Industries, Darien IL, USA). Technetium is strongly retained from neutral $\mathrm{pH}$ solutions by the material, while the isobaric interfering elements of $\mathrm{Mo}$ is only weakly retained and $\mathrm{Ru}$ is not retained at all. Molybdenum has several isotopes, one of which is mass 97 , which is $9.5 \%$ of natural abundance; ruthenium, also multiisotopic, has a $12.7 \%$ abundant peak at mass 99 . Technetium may be removed from the extraction material using dilute nitric acid which is injected into the ICP-MS for isotope ratio determination [1].

The custom elemental equation written into the SOLA software corrects the $\mathrm{m} / \mathrm{z}=97$ peak for any remaining Mo based on the $\mathrm{m} / \mathrm{z}=95$ peak, assuming natural mass abundances of the Mo isotopes. The $\mathrm{m} / \mathrm{z}=99$ peak is corrected for any remaining $\mathrm{Ru}$ based on the $\mathrm{m} / \mathrm{z}=101$, again assuming natural abundances of the $R u$ isotopes. The $m / z=99$ correction is usually negligible, (Figure 2A) however the $\mathrm{m} / \mathrm{z}=97$ correction may be significant in some samples, (Figure 2B). The 99/97 ratio is measured using the multiplier detector of the SOLA set at a dwell time of $16 \mathrm{msec} / \mathrm{channel}, 16 \mathrm{channel} / \mathrm{amu}, 50$ passes per scan. Four scans are performed during each sample analysis. A five minute rinse, using a solution of $1 \%$ nitric acid, is performed between each sample analysis.

Iodine-129 The initial procedure development to analyze ${ }^{129} \mathrm{I}$ by ICP-MS used a Meinhart nebulizer and Scott's spray chamber for sample introduction. We were not able to eliminate the xenon interference at $\mathrm{m} / \mathrm{z}=129,(26.4 \%$ abundant peak of natural xenon) in aqueous samples, (Figure 3A) thus we had to develop a concentration procedure to achieve our desired detection limit of less than $37 \mathrm{mBq} / \mathrm{L},(1 \mathrm{pCi} / \mathrm{L})[2]$. With the substitution of a CETAC ultrasonic nebulizer for sample introduction the Xe interference was no longer apparent, (Figure 3B). The lack of xenon in the sample spectra when using the ultrasonic nebulizer vs the Meinhart 
nebulizer for sample introduction may be due to the different mass flow conditions of the carrier gas, changing the plasma characteristics, thus ionizing the xenon contaminant of the argon gas less efficiently under the ultrsonic nebulizer flow conditions, [9]. We are still using the sample concentration procedure prior to analysis to lower our detection limit even further. Sample analysis for determination of ${ }^{129} \mathrm{I}$ requires two ICP-MS measurements. The natural iodine, $\left({ }^{127} \mathrm{I}\right)$ concentration is measured in the original sample using indium as an internal standard. This value is then used as the tracer concentration for the isotope dilution calculation. After adjustment of the oxidation state the iodine is extracted onto an anion exchange resin, (AG 1X8, chloride form, BioRad Laboratories, Richmond CA, USA). The iodine is then eluted from the resin with dilute nitric acid which is injected into the ICP-MS for isotope ratio determination.

The $\mathrm{m} / \mathrm{z} 129 / 127$ ratio is measured within a few days of sample preparation to minimize iodine loss from the nitric acid solution. The $129 / 127$ ratio is multiplied by the measured iodine, $\left({ }^{127} \mathrm{I}\right)$ concentration to determine the ${ }^{129} \mathrm{I}$ concentration in the sample. The $129 / 127$ ratio is often measured using the multiplier detector of the SOLA set at a dwell time of 16 msec/channel, 16 channel/amu, 50 passes per scan. Four scans are performed during each sample analysis. For samples with high natural iodine concentrations both the Faraday detector and the multiplier detector of the SOLA are used, [2]. The ${ }^{127} \mathrm{I}$ count rate is measured on the Faraday detector and the ${ }^{129} \mathrm{I}$ on the multiplier, with indium used as a normalizing factor to determine the $129 / 127$ ratio. A five minute rinse, using a solution of $1 \%$ nitric acid, is performed between each sample analysis.

Tritium The tritium concentration of the samples was determined by liquid scintillation spectrometry (LSC). Three milliliters of sample were pipetted into a $25 \mathrm{ml}$ plastic scintillation vial. Nineteen milliliters of Opti-fluor liquid scintillation cocktail were added to each sample. Samples were counted three times, ten minutes each count, using the blank correction and automatic quench correction curves of the Tri-Carb counter.

\section{Results}

The results from the analyses completed during this study are shown in Tables 1-5. The pH, conductivity and temperature were recorded in the field at the time of sample collection. The reported ${ }^{3} \mathrm{H}$ results are the mean of the three LSC counts. The mean ${ }^{3} \mathrm{H}$ results had an average relative standard deviation, (RSD) of less than 5\% and so are not reported in the tables, (individual counting errors often were greater than the $5 \% \mathrm{RSD}$ but were not propagated). The ${ }^{99} \mathrm{Tc}$ and ${ }^{129} \mathrm{I}$ activities are calculated based on the mean of the four scans completed for each sample analyzed by the ICP-MS. The error associated with the ${ }^{99} \mathrm{Tc}$ data is the standard deviation of the mean; it is due to the variation in the scan results only. The ${ }^{129} \mathrm{I}$ error incorporates the standard deviation on the 129/127 measurement as well as the standard deviation on the iodine, $\left({ }^{127} \mathrm{I}\right)$ concentration measurement. 
The large error associated with much of the ${ }^{99} \mathrm{Tc}$ and ${ }^{129} \mathrm{I}$ data is due to the concentration being close to the detection limit of the technique. The detection limit of the procedure for ${ }^{99} \mathrm{Tc}$, based on a one litre sample, is below $.02 \mathrm{~Bq} / \mathrm{L}(0.5 \mathrm{pCi} / \mathrm{L})$; the mean and standard deviation, (one sigma) of several reagent blank samples run concurrently with these samples was $0.013 \pm 0.004 \mathrm{~Bq} / \mathrm{L}(0.35 \pm 0.11 \mathrm{pCi} / \mathrm{L})$. This study was designed as a scoping study of the surface waters of the SRS, thus this detection limit was sufficient. The Savannah River Technology Center, (SRTC) also has a procedure to determine ${ }^{99} \mathrm{Tc}$ by PositiveThermal Ionization Mass Spectrometry PTI-MS, [10]. The instrumental detection limit for ${ }^{99} \mathrm{Tc}$ by PTI-MS is $0.03 \mathrm{mBq} / \mathrm{L}(\mathrm{O} .7 \mathrm{fCi} / \mathrm{L})$. The procedural detection limit, based on a series of samples collected in the Arctic, is $0.3 \mathrm{mBq} / \mathrm{L}$ ( $8 \mathrm{fCi} / \mathrm{L}$ ) based on a $\mathrm{IL}$ sample [11].

Because the concentration of the tracer enters into the calculation of detection limit for isotope dilution techniques, it is not so straight forward to state a detection limit for the ${ }^{129}$ I measurement. The iodine concentration of the streams sampled during this study varied from 1-30 ppb depending on sample location and season. The SOLA ICP-MS is capable of measuring a 129/127 ratio as small as $10^{-10}$; typical reagent blank $129 / 127$ ratios of $10^{-5}$ were measured concurrently with these samples, while typical sample ratios were 0.01 to 0.001 . If the five sample locations expected to have no influence from the SRS operations, (iodine concentration from 1-7 ppb) are used to estimate a detection limit for this study, the average $(n=21)$ is $0.022 \mathrm{~Bq} / \mathrm{L}(0.60 \mathrm{pCi} / \mathrm{L})$, suggesting the detection limit for ${ }^{129} \mathrm{I}$ based on this procedure using a one liter sample is slightly over $0.02 \mathrm{~Bq} / \mathrm{L}(0.5 \mathrm{pCi} / \mathrm{L})$.

Due to the large errors on the individual sample results only general conclusions can be drawn regarding ${ }^{99} \mathrm{Tc}$ and ${ }^{129} \mathrm{I}$ in the surface waters of the SRS. The stream system most influenced by SRS activities is the Fourmile Branch system. The H-3 concentration below the F and $\mathrm{H}$ seepage basin inflows is over 100 times greater than the headwaters of the stream. Elevated ${ }^{3} \mathrm{H}$ concentrations were also found in Indian Grave Branch, and above background levels of ${ }^{3} \mathrm{H}$ were found in Steel Creek and occasionally in Upper Three Runs Creek, (U3R) below the ETF. The highest ${ }^{99} \mathrm{Tc}$ and ${ }^{129} \mathrm{I}$ activities were found in Fourmile Branch.

To better understand the data generated during this study, the results were averaged over the 2-2 1/2 year study period. Figures 5-7 plot the mean concentration of ${ }^{3} \mathrm{H},{ }^{99} \mathrm{Tc}$ and ${ }^{129} \mathrm{I}$ in the streams for all analyses completed, for which at least three samples were analyzed, versus the sampling location. The results are plotted in the same order as which the data is presented in the tables; top to bottom is presented left to right. Note that the ${ }^{3} \mathrm{H}$ data is plotted on a logarithmic scale, (Figure 5) while the ${ }^{99} \mathrm{Tc}$ and ${ }^{129} \mathrm{I}$ are plotted on a linear scale, (Figure 6 and 7, respectively). The first five sample locations are above the SRS influence and can be considered a background level to which the other data can be compared. These are the Hollow Creek location and the U3R and Tinker Creek samples collected at both Highway 278 and Road 2.1.

As seen in Figure 5, there are several locations where an increase in the ${ }^{3} \mathrm{H}$ concentration is obvious. Below the ETF on U3R, (sample locations 9 and 10) there appears to be an increase 
in the ${ }^{3} \mathrm{H}$ concentration to almost double the background levels. As stated earlier the ETF process can not remove $\mathrm{H}-3$ from the wastewater it processes and so this is not unexpected. As seen in the individual data sets, (Tables $2-5$ ) the ${ }^{3} \mathrm{H}$ in U3R below the ETF is sporadic. ETF releases processed water in batches to U3R, the releases lasting less than one day, occurring every few weeks, resulting in occasional ${ }^{3} \mathrm{H}$ concentration increases. There does not appear to be any increase in ${ }^{99} \mathrm{Tc}$ concentration in the stream system below the SRS activities, including the ETF, (Figure 6). It has been noted in the past that the ${ }^{129} \mathrm{I}$ concentration in the U3R below SRS activates is slightly higher than above the SRS; this is thought to be due to atmospheric deposition of ${ }^{129}$ I released from the separation areas stacks [5]. In this study we did find higher ${ }^{129}$ I concentrations in the lower U3R, especially at Box Landing Road, (Figure 7 , sample location 10).

Elevated ${ }^{3} \mathrm{H},{ }^{99} \mathrm{Tc}$ and ${ }^{129} \mathrm{I}$ in Fourmile Branch can be attributed to migrating groundwater from below the F- and $\mathrm{H}$-area seepage basins. Fourmile Branch, below Road 4, (sample location 13) is influenced by the migrating groundwater from below the seepage basins. The groundwater is known to have a higher conductivity and contains elevated ${ }^{3} \mathrm{H}$. Based on 1985-1987 averages, approximately $8.9 \times 10^{13} \mathrm{~Bq} / \mathrm{L}(2400 \mathrm{Ci} / \mathrm{yr})$ of ${ }^{3} \mathrm{H}$ migrate from the $\mathrm{F}$ area seepage basins, approximately $2.2 \times 10^{14} \mathrm{~Bq} / \mathrm{L}(6000 \mathrm{Ci} / \mathrm{yr})$ from the $\mathrm{H}$-area seepage basins [3]. Technetium-99 has been detected in the groundwater of several $\mathrm{F}$ and $\mathrm{H}$ area seepage basin monitoring wells. Along the seepline, ${ }^{99} \mathrm{Tc}$ concentrations of up to $44.4 \mathrm{Bg} / \mathrm{L}$ $(1200 \mathrm{pCi} / \mathrm{L})$ and $10.36 \mathrm{~Bq} / \mathrm{L}(280 \mathrm{pCi} / \mathrm{L})$ were measured below $\mathrm{F}$ and $\mathrm{H}$ area basins, respectively [4]. Below the $\mathrm{F}$ area seepline, ${ }^{129} \mathrm{I}$ concentrations as high as $15.17 \mathrm{~Bq} / \mathrm{L}(410 \mathrm{pCi} / \mathrm{L})$ have been measured; as high as $1.85 \mathrm{~Bq} / \mathrm{L}(50 \mathrm{pCi} / \mathrm{L})$ below the $\mathrm{H}$ area seepline [5]. The headwaters of Fourmile Branch also appear to have excess ${ }^{3} \mathrm{H}$ possibly due to atmospheric deposition and surface runoff within the upper Fourmile Branch. Technetium- 99 and ${ }^{129}$ I do not appear elevated above the seepage basin inflows.

The ${ }^{3} \mathrm{H}$ concentration in Indian Grave is influenced by groundwater from the $\mathrm{K}$ area seepage basin, while Pen Branch at Road B, (sample location 17) appears to receive little aqueous ${ }^{3} \mathrm{H}$ input. After mixing with Indian Grave the ${ }^{3} \mathrm{H}$ concentration of Pen Branch significantly increases, (sample location 19 ). The ${ }^{99} \mathrm{Tc}$ concentration in the stream system does not appear to vary greatly with season or location. The average ${ }^{99} \mathrm{Tc}$ concentration may increase slightly downstream. The ${ }^{129}$ I concentration in Pen Branch at both sampling locations appears higher than in Indian Grave, however this conclusion is supported by only one of the four sampling periods.

The ${ }^{3} \mathrm{H}$ concentration in Steel Creek is significantly above background levels in all sample locations. There appears to be a sporadic input of ${ }^{3} \mathrm{H}$, probably from $\mathrm{P}$ area, which is then well mixed in L Lake and the lower Steel Creek system, (sample location 22 and 23). Technetium-99 may be being introduced to Steel Creek from $\mathrm{P}$ area as is ${ }^{3} \mathrm{H}$. The average ${ }^{99} \mathrm{Tc}$ concentration in Steel Creek below $P$ area, (sample location 20) appears slightly higher than the concentration in L Lake and lower Steel Creek. Elevated ${ }^{99} \mathrm{Tc}$ was found in two monitoring wells downgradient from the $\mathrm{L}$ area Oil and Chemical Basin. Due to the large dilution 
effect no ${ }^{99} \mathrm{Tc}$ in excess of the normal background levels was found in L Lake. The amount of variation in ${ }^{129} \mathrm{I}$ concentration in the Steel Creek samples is similar to the variation in the above SRS samples thus it may not be significant.

Tritium concentrations in Pond B and Par Pond are slightly above background. Below the Par Pond dam, ${ }^{3} \mathrm{H}$ concentrations are decreased in L3R by dilution due to increasing water flow between the dam and the Savannah River. No input of ${ }^{99} \mathrm{Tc}$. or ${ }^{129} \mathrm{I}$ was detectable from operations of the SRS in the entire L3R system.

\section{Conclusions}

Elevated concentrations of ${ }^{3} \mathrm{H},{ }^{99} \mathrm{Tc}$ or ${ }^{129} \mathrm{I}$ were measured in some surface waters of the SRS. The higher concentrations were associated with ground water migration from beneath old seepage basins. The seepage basins were used for the disposal of waste water containing low concentrations of chemicals and radionuclides from the SRS operations and were closed in 1988. The SRS streams carrying the radionuclides discharge into the Savannah River. After mixing with the Savannah River, all radionuclide concentrations are well below any applicable regulatory guidelines.

Previous to this study, few measurements of ${ }^{99} \mathrm{Tc}$ or ${ }^{129} \mathrm{I}$ in surface streams of the SRS existed, principally due to the difficulty in measuring these isotopes. The developed technique is rapid, (samples can be processed in batches, six analyses per hour can be analyzed by the ICP-MS protocol) and offers detection limits suitable for environmental monitoring requirements.

\section{Acknowledgments}

The authors wish to thank Sharon Redd for processing the samples in the laboratory and Sandra Nappier for operating the ICP-MS. Samples were collected by Sharon Redd, Raymond Roseberry, Ron Johnson, Richard Penix and Brian Antonicelli.

The information in this document was produced during activities performed under Contract No. DE-AC09-89SR18035 for the U.S. Department of Energy. The U.S. Government retains a non-exclusive, royalty-free license in and to any copyright covering this document, along with the right to reproduce and to authorize others to reproduce all or part of the copyright 
paper.

\section{References}

1. Beals, D.M., 1992, "Determination of Technetium-99 in Aqueous Samples by Isotope Dilution Inductively Coupled Plasma-Mass Spectrometry." Presented at the 3rd International Conference on Nuclear and Radiochemistry, Vienna, September 1992 and submitted for publication in the Journal of Radioanalytical and Nuclear Chemistry.

2. Beals, D.M., P. Chastagner and P.K. Turner, 1992, "Analysis of Iodine-129 in Aqueous Samples by Inductively Coupled Plasma-Mass Spectrometry." Presented at the 38th Annual Conference on Bioassay, Analytical and Environmental Radiochemistry, Santa Fe NM, November 1992.

3. Murphy, C.E., Jr., W.H. Carlton, L.R. Bauer, D.W. Hayes, W.L. Marter, C.C. Zeigler, R.L. Nichols, R.N. Strom, B.R. del Carmen, D.M. Hamby, D.D. Hoel and D.E. Stephenson, 1993, "Assessment of Tritium in the Savannah River Site Environment." WSRC-TR-93-214, Westinghouse Savannah River Co., Aiken SC.

4. Carlton, W.H., M. Denham and A.G. Evans, 1993, "Assessment of Technetium in the Savannah River Environment." WSRC-TR-93-217, Westinghouse Savannah River Co., Aiken SC.

5. Kantelo, M.V., L.R. Bauer, W.L. Marter, C.E. Murphy, Jr. and C.C. Zeigler, 1990, "Radioiodine in the Savannah River Site Environment." WSRC-RP-90-424-1, Westinghouse Savannah River Co., Aiken SC.

6. Turcotte, M-D.S., 1982, "Environmental Behavior of Technetium-99." DP-1644, du Pont de Nemours \& Co., Savannah River Plant and Laboratory, Aiken SC.

7. Till, J.E., F.O. Hoffman and D.E. Dunning Jr., 1979, "A New Look at Tc-99 Releases to the Atmosphere." Health Physics, 36, 21-30.

8. Evans, A.G., L.R. Bauer, J.S. Haselow, H.L. Martin, W.L. McDowell and J.B. Pickett, 1992, "Uranium in the Savannah River Site Environment." WSRC-RP-92-315, Westinghouse Savannah River Co., Aiken SC.

9. Houk, Sam (personal communication).

10. Pochowski, J.M. and D.M. Beals, 1993, "Determination of Subpicogram Quantities of Technetium-99 in Environmental Samples by Positive Thermal Ionization Mass Spectrometry". Proceedings of the 41st ASMS Conference on Mass Spectrometry and Allied Topics, San Francisco, CA, May 1993.

11. Beals, D,M. and E. Landa (unpublished data). 


\section{Figures and Tables}

Figure 1. Map Showing Location of the Savannah River Site.

Figure 2. (A) SRS MapShowing the Major Streams,Facilities and Sampling Locations.

(B) Listing and Descriptions of each Sampling Location.

Figure 3. Typical Sample Spectra for Tc-99 Analysis Without (A) Molybdenum Interference and with Remaining Molybdenum (B).

Figure 4. Typical SampleSpectra for I-129Analysis using a Meinhart Nebulizer (A) and using the CETAC Ultrasonic Nebulizer (B).

Figure 5. Plot of Average H-3 Concentration Versus SampleLocation.

Figure 6. Plot of Average Tc-99 Concentration Versus Sample Location.

Figure 7. Plot of Average I-129 Concentration Versus SampleLocation.

Table 1. Savannah River Site Sample Collection Sites And Results Collection Dates: July 1992

Table 2. Savannah River Site Sample Collection Sites And Results Collection Dates: 18 January to 1 February 1993.

Table 3. Savannah River Site Sample Collection Sites And Results Collection Dates: 15-16 July 1993.

Table 4. Savannah River Site Sample Collection Sites And Results Collection Dates: 7-9 February 1994.

Table 5. Savannah River Site Sample Collection Sites And Results Collection Dates: 6-7 June 1994. 


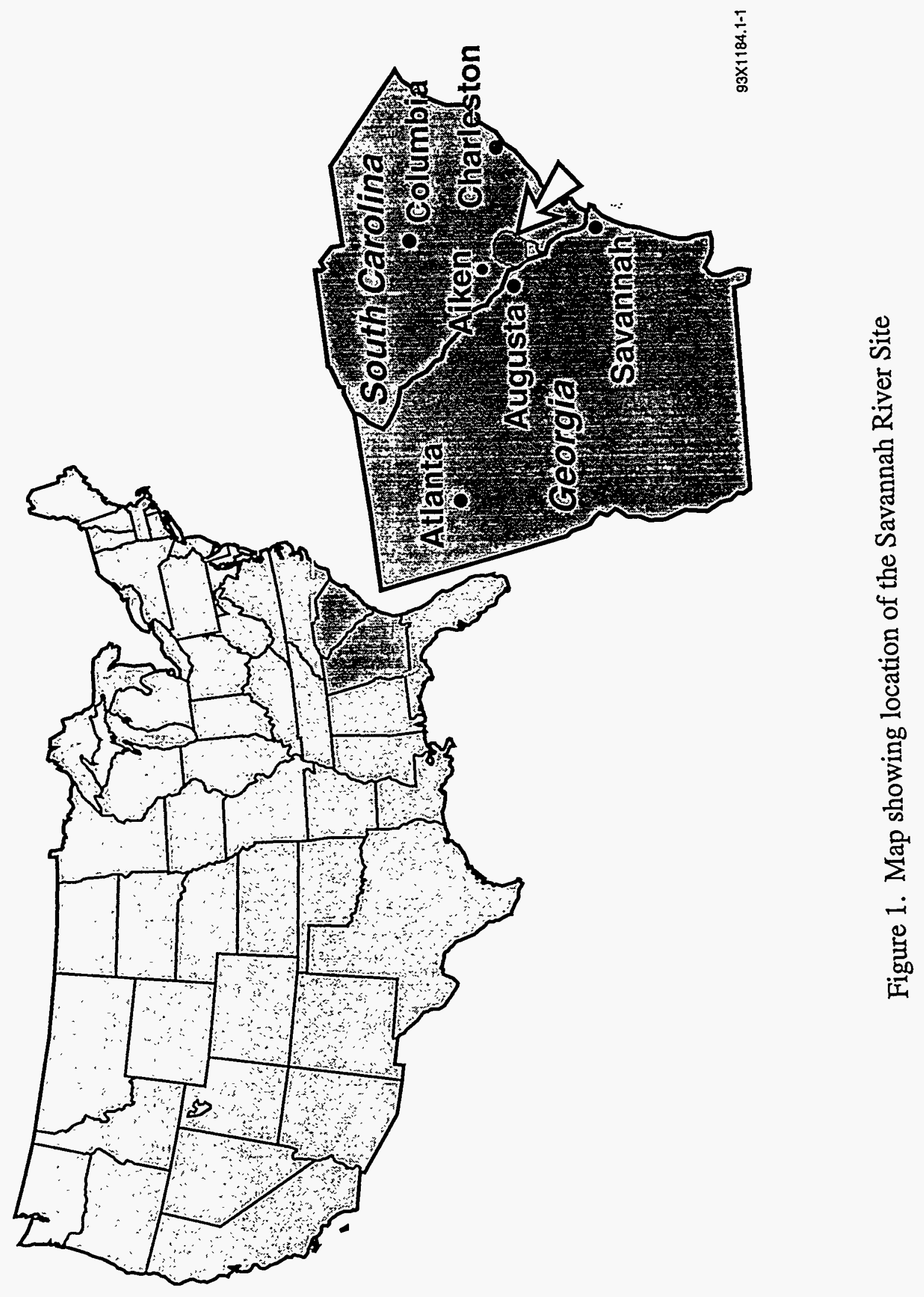




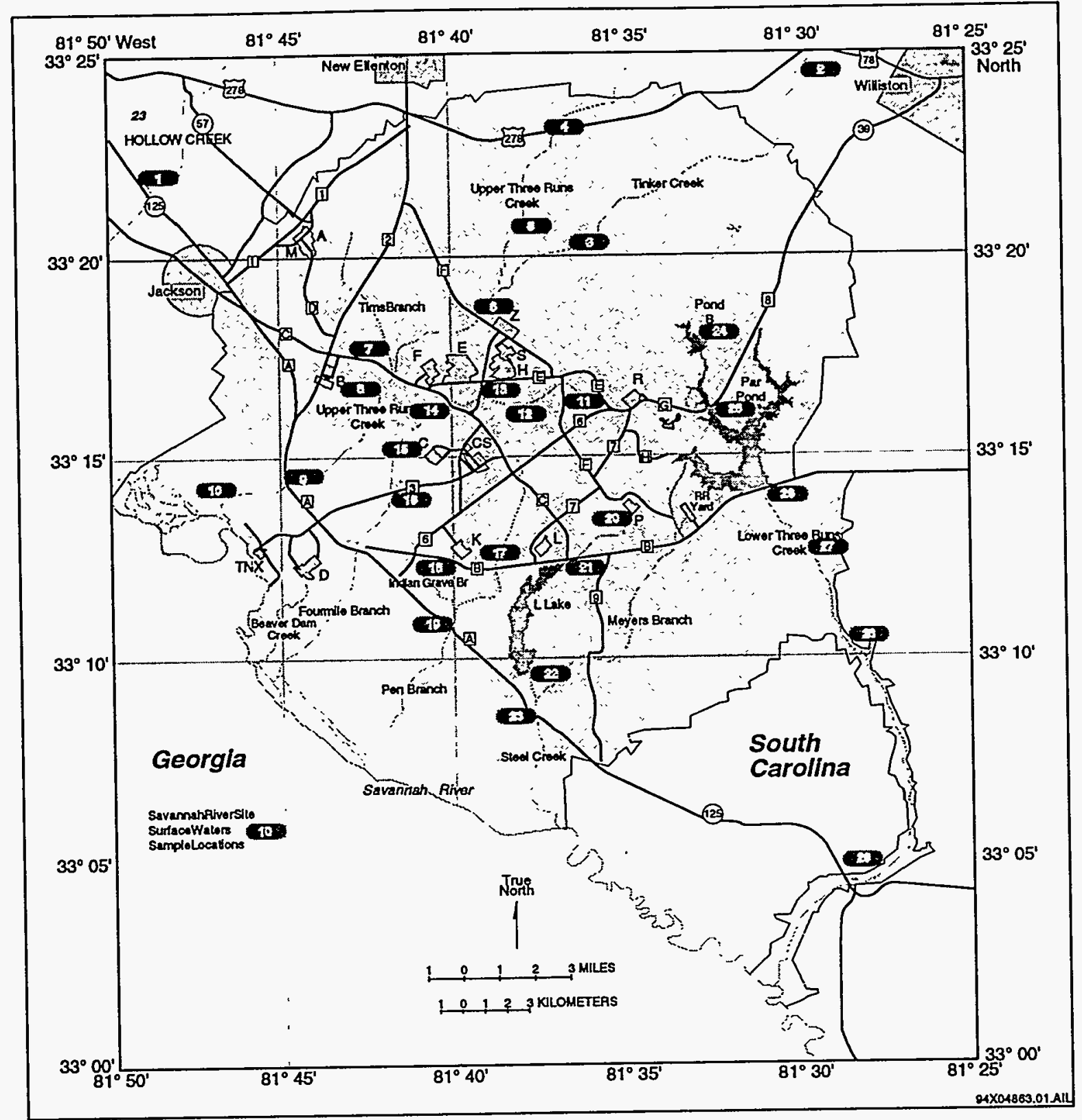

Figure 2A. Savannah River Site Surface Water Sample Locations 
Figure 2b. Savannah River Site Surface Water Sample Sites and Description of Location

\begin{tabular}{|c|c|c|}
\hline Number & Sample Location & Sample Description \\
\hline 1 & Hollow Creek & off site background \\
\hline \multicolumn{3}{|c|}{ Upper Three Runs Creek system (U3R) } \\
\hline 2 & Tinker Ck @ Hwy 278 & above site activities \\
\hline 3 & Tinker Ck @ Road 2.1 & above site activities \\
\hline 4 & U3R @ Hwy 278 & above site activities \\
\hline 5 & U3R @ Road 2.1 & above site activities \\
\hline 6 & U3R @ RoadF & below mix of U3R \& Tinker Creek \\
\hline 7 & Tim's Branch & prior to enter U3R \\
\hline 8 & U\#R @ Road C & above ETF outfall \\
\hline 9 & U3R @ Road A & below ETF outfall \\
\hline 10 & U3R @ Box Landing Road & below site activities \\
\hline \multicolumn{3}{|c|}{ Fourmile Branch system (4MB) } \\
\hline 11 & 4MB @ Road F & headwater \\
\hline 12 & 4MB @ Road E-1 & above seepage basins \\
\hline 13 & 4MB @ Road 4 & below $\mathrm{H}$ seepage basins \\
\hline 14 & 4MB @ Road C & below F seepage basins \\
\hline 15 & 4MB @ Road A-7 & below $\mathrm{C}$ reactor discharge \\
\hline 16 & 4MB@Road A & below site activities \\
\hline \multicolumn{3}{|c|}{ Pen Branch system (PB) } \\
\hline 17 & PB @ Road B & above $\mathrm{K}$ reactor \\
\hline 18 & Indian Grave @ Road B & below $\mathrm{K}$ seepage \\
\hline 19 & PB @ Road A & below mix of Indian Grave \& PB \\
\hline \multicolumn{3}{|c|}{ Steel Creek system (SC) } \\
\hline 20 & $\mathrm{SC}$ below $\mathrm{P}$ & headwater, $\mathrm{P}$ reactor outfall \\
\hline 21 & SC@Road B & top of lake \\
\hline 22 & L Lake outfall & below dam \\
\hline 23 & SC@Road A & prior to mix with $\mathrm{PB}$ \\
\hline \multicolumn{3}{|c|}{ Lower Three Runs Creek system (L3R) } \\
\hline 24 & Pond B & cooling for P \& R reactor \\
\hline 25 & bubble up & inflow to Par Pond \\
\hline 26 & L3R @ road B & below Par Pond dam \\
\hline 27 & L3R @ Donora Station & below site activities \\
\hline 28 & L3R @ Patterson Mill & below site activities \\
\hline 29 & L3R @ Hwy 125 & prior to entrance to Savannah River \\
\hline
\end{tabular}


Figure 3A Typical Sample Spectra for ${ }^{99}$ Tc without Molybdenum Interference

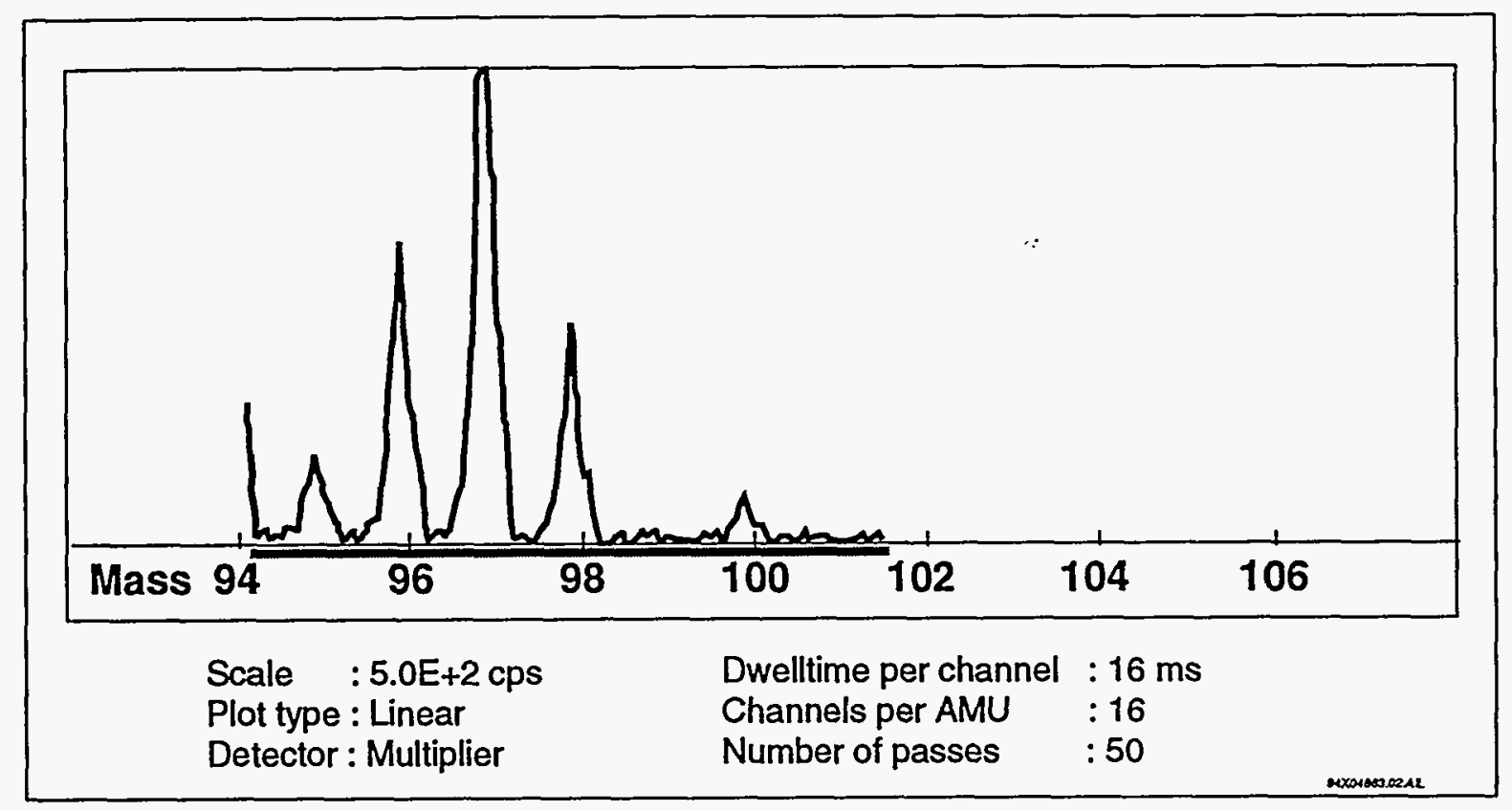

Figure BA Typical Sample Spectra for ${ }^{99} \mathrm{Tc}$ with Remaining Molybdenum

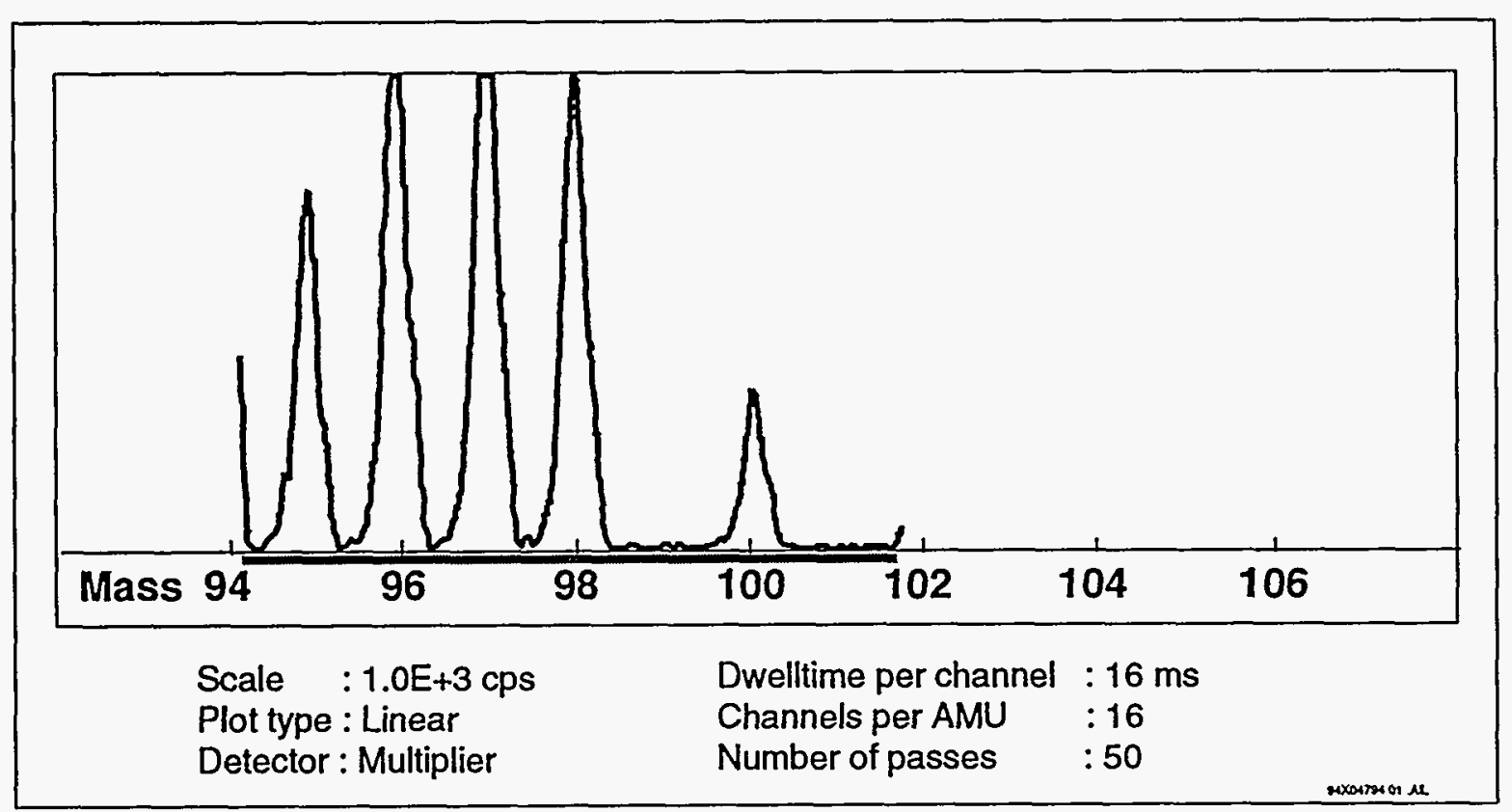


Figure 4A. Typical Sample Spectra for ${ }^{129}$ I Analysis using a Meinhart Nebulizer

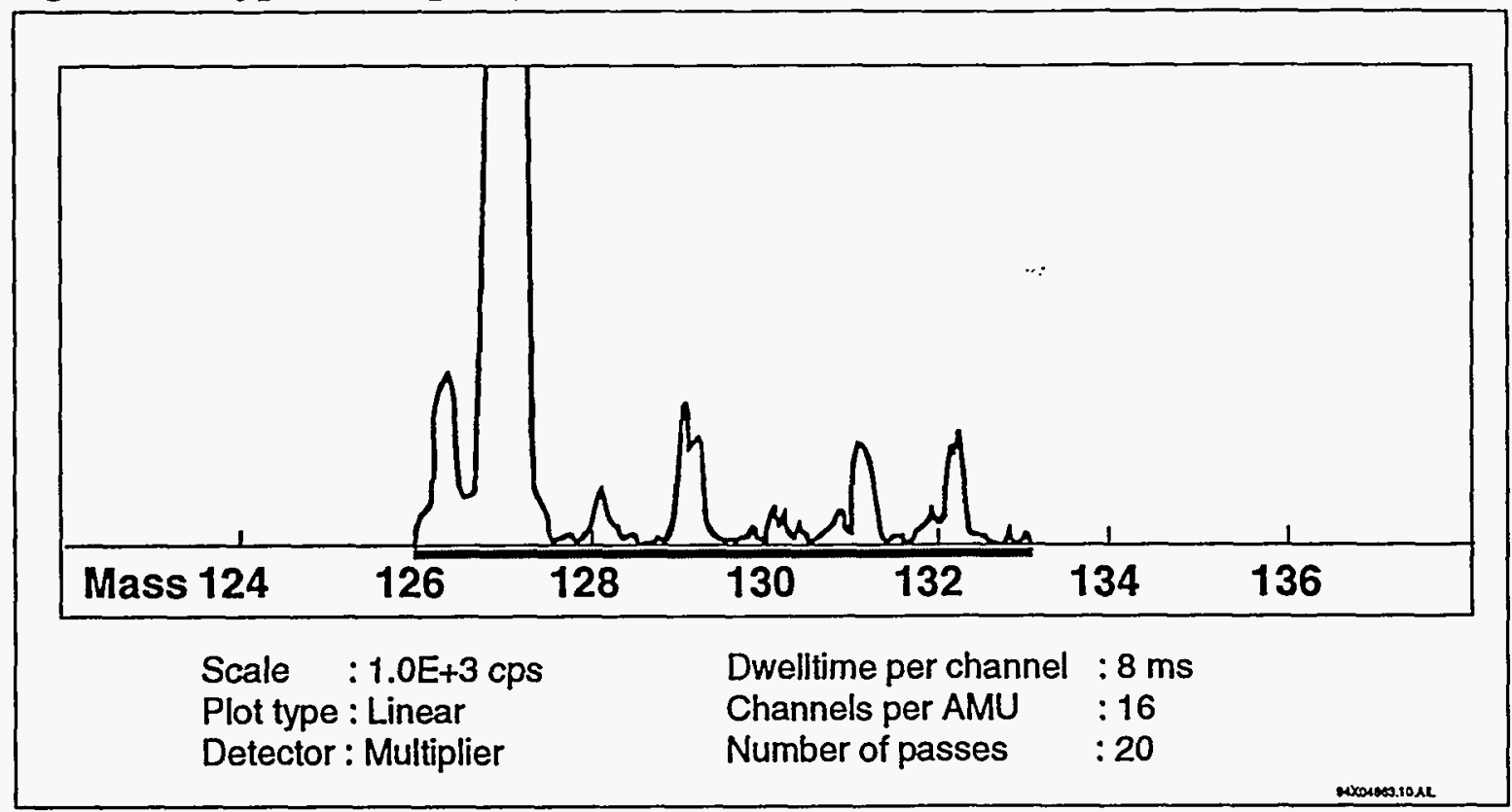

Figure 4B. Typical Sample Spectra for 129 I using the CETAC Ultrasonic Nebulizer

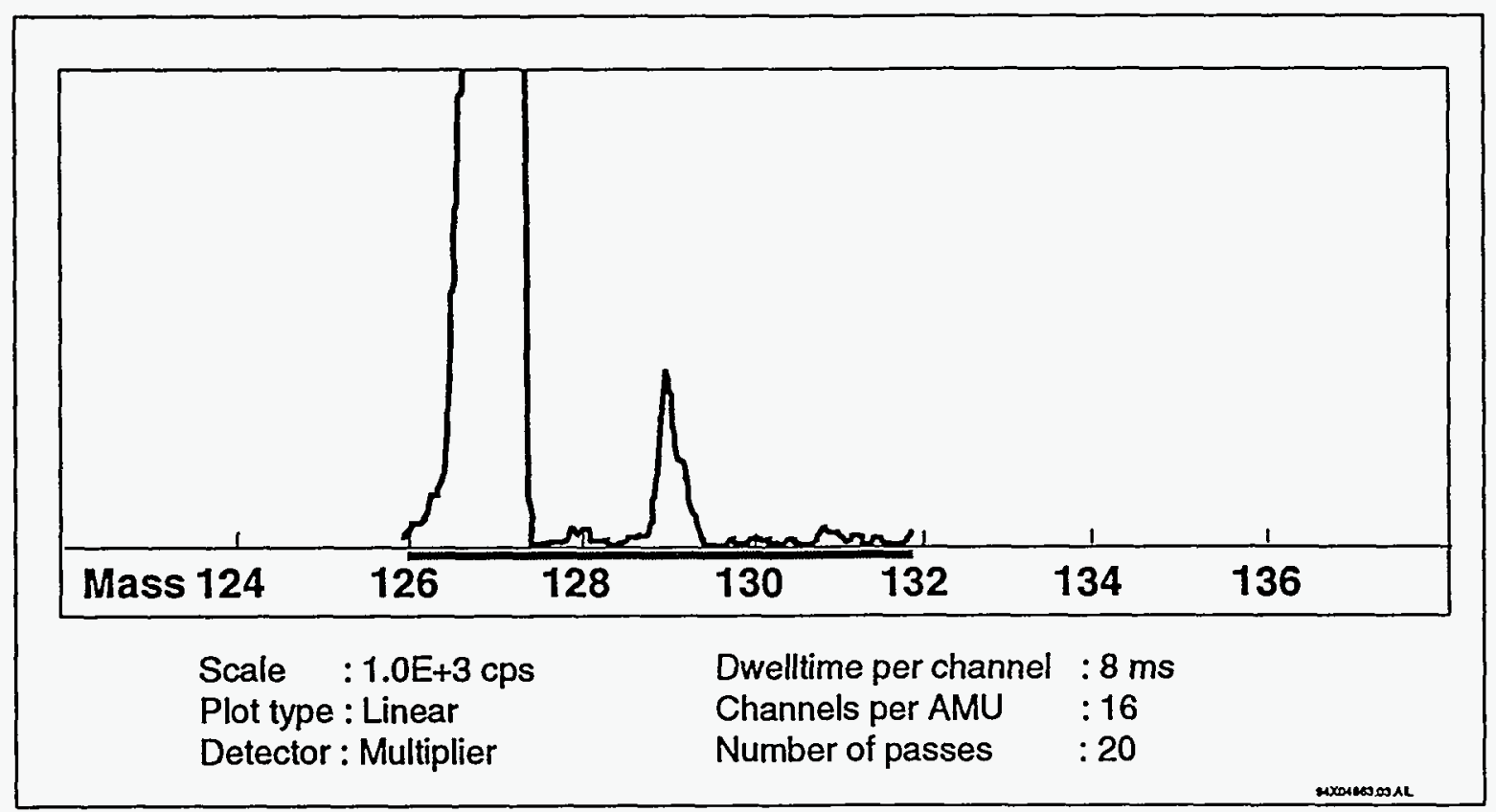




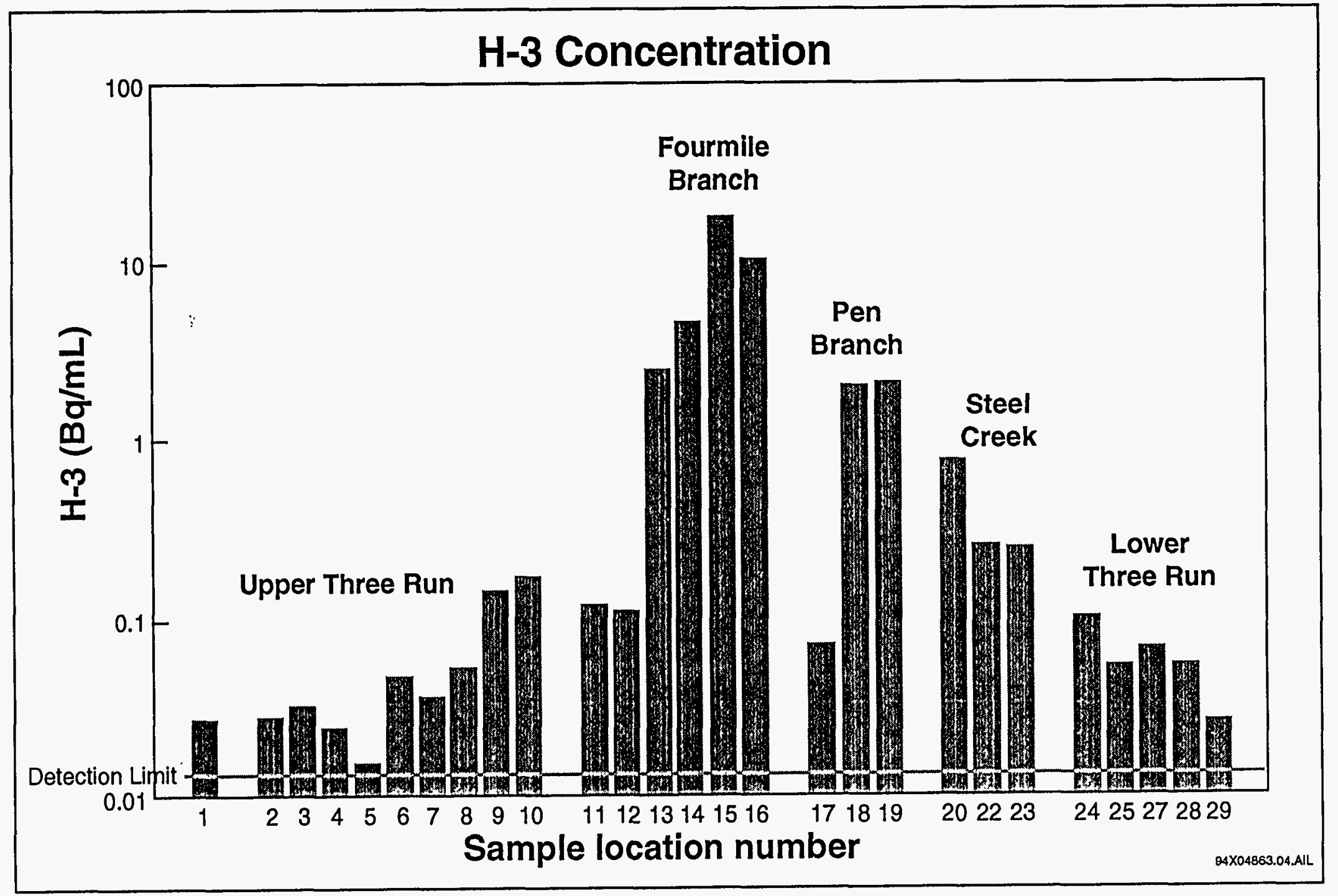

Figure 5. Tritium concentration plotted against sample location. 


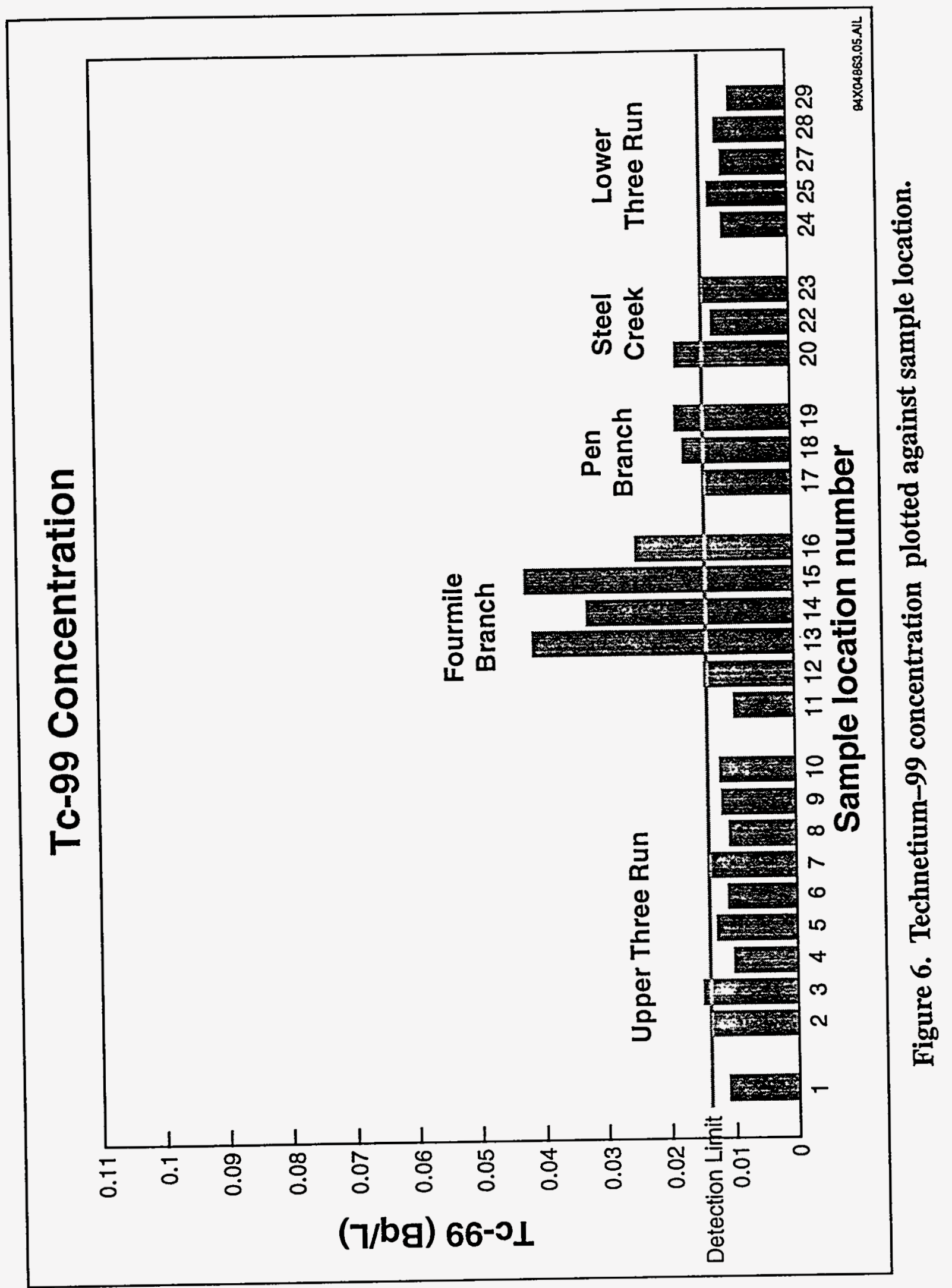




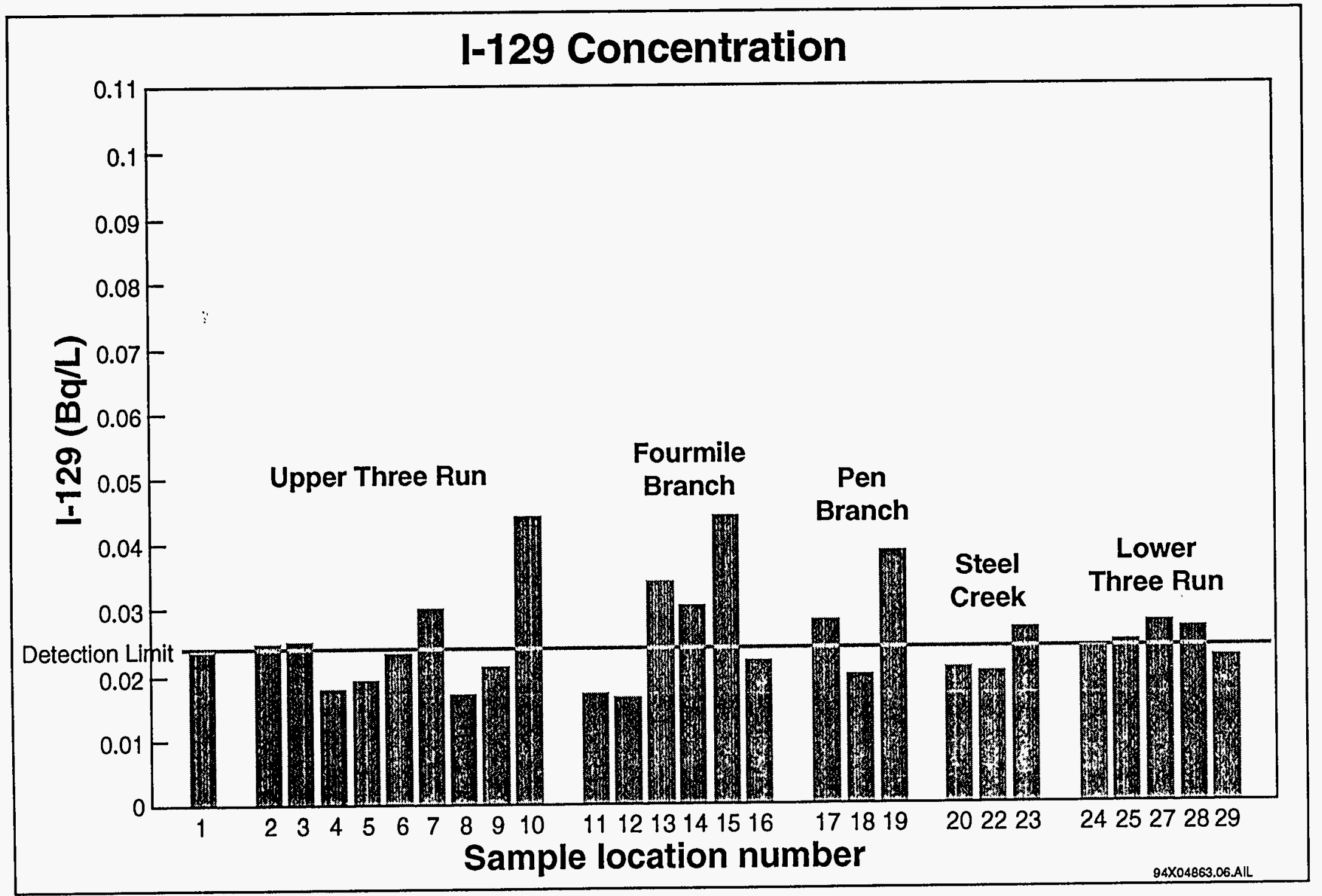

Figure 7. Iodine-129 concentration plotted against sample location. 
Table 1. Savannah River Site Sample Collection Sites And Results Collection Dates: July 1992

\begin{tabular}{crrrrr}
$\begin{array}{c}\text { Sampling } \\
\text { Site }\end{array}$ & Bq/L & I-129 & & \multicolumn{2}{c}{ Tc-99 } \\
& & & & Bq/L & \% RSD \\
11 & 0.001 & 82 & $\cdots$ & 0.008 & 5 \\
12 & 0.001 & 119 & & 0.007 & 17 \\
13 & 0.085 & 55 & 0.115 & 81 \\
14 & 0.080 & 38 & & 0.076 & 71 \\
15 & 0.041 & 40 & 0.115 & 59 \\
16 & 0.011 & 25 & 0.028 & 40
\end{tabular}


Table 2. Savannah River Site Sample Collection Sites And Results Collection Dates: 18 January - 1 February 1993

\begin{tabular}{|c|c|c|c|c|c|c|c|c|}
\hline $\begin{array}{l}\text { Sampling } \\
\text { Site }\end{array}$ & pH & $\begin{array}{l}\text { conduct. } \\
\mathrm{mS}\end{array}$ & $\begin{array}{l}\text { temp. } \\
{ }^{\circ} \mathrm{C}\end{array}$ & $\begin{array}{l}{ }^{3} \mathbf{H} \\
\mathbf{B q} / \mathbf{m l}\end{array}$ & $\begin{array}{l}{ }^{129} \mathrm{I} \\
\mathrm{Bq} / \mathrm{mL}\end{array}$ & $\begin{array}{l}\text { RSD } \\
\%\end{array}$ & $\begin{array}{l}{ }^{99} \mathrm{Tc} \\
\mathrm{Bq} / \mathrm{L}\end{array}$ & $\begin{array}{l}\text { RSD } \\
\%\end{array}$ \\
\hline 1 & 6.72 & 0.016 & 11.9 & 0.032 & 0.026 & 25 & 0.015 & 100 \\
\hline 1 & 6.72 & 0.016 & 11.9 & 0.026 & 0.017 & 37 & 0.013 & 51 \\
\hline 2 & 6.17 & 0.022 & 9.9 & 0.019 & 0.008 & 29 & 0.007 & 118 \\
\hline 3 & 5.97 & 0.017 & 9.7 & 0.044 & 0.027 & 53 & 0.028 & 87 \\
\hline 4 & 5.28 & 0.012 & 11.6 & 0.020 & 0.011 & 24 & 0.015 & 129 \\
\hline 6 & 5.87 & 0.014 & 10.3 & 0.061 & 0.010 & 26 & 0.011 & 44 \\
\hline 7 & 6.09 & 0.038 & 13.0 & 0.049 & 0.009 & 23 & 0.012 & 23 \\
\hline 8 & 5.59 & 0.015 & 11.2 & 0.079 & 0.013 & 32 & 0.008 & 41 \\
\hline 9 & 5.98 & 0.015 & 11.0 & 0.061 & 0.022 & 52 & 0.010 & 37 \\
\hline 11 & 5.39 & 0.017 & 9.6 & 0.103 & 0.028 & 26 & 0.010 & 18 \\
\hline 12 & 5.38 & 0.015 & 11.4 & 0.115 & 0.015 & 17 & 0.022 & 16 \\
\hline 13 & 5.99 & 0.046 & 11.8 & 1.530 & 0.015 & 24 & 0.035 & 35 \\
\hline 14 & 6.02 & 0.047 & 11.4 & 4.375 & 0.012 & 16 & 0.025 & 35 \\
\hline 15 & 5.95 & 0.050 & 11.2 & 15.774 & 0.016 & 10 & 0.021 & 56 \\
\hline 16 & 6.22 & 0.044 & 11.7 & 10.020 & 0.016 & 12 & 0.032 & 32 \\
\hline 17 & 6.55 & 0.036 & 8.1 & 0.156 & 0.025 & 15 & 0.030 & 70 \\
\hline 18 & 6.91 & 0.040 & 9.0 & 1.793 & 0.017 & 10 & 0.019 & 23 \\
\hline 19 & 6.16 & 0.040 & 11.5 & 2.308 & 0.018 & 25 & 0.026 & 110 \\
\hline 20 & 7.15 & 0.048 & 12.0 & 0.131 & 0.012 & 42 & 0.007 & 37 \\
\hline 22 & 6.99 & 0.052 & 9.9 & 0.275 & 0.016 & 18 & 0.009 & 41 \\
\hline 23 & 6.29 & 0.051 & 12.4 & 0.250 & 0.015 & 8 & 0.012 & 75 \\
\hline 24 & 6.87 & 0.014 & 12.7 & 0.140 & 0.017 & 33 & 0.010 & 10 \\
\hline 24 & 7.41 & 0.038 & 12.9 & 0.083 & 0.007 & 50 & 0.011 & 118 \\
\hline 27 & 6.17 & 0.038 & 11.5 & 0.090 & 0.017 & 35 & 0.009 & 76 \\
\hline 28 & 6.28 & 0.046 & 12.0 & 0.087 & 0.009 & 21 & 0.018 & 100 \\
\hline 29 & 6.27 & 0.043 & 11.2 & 0.035 & 0.009 & 42 & 0.012 & 49 \\
\hline
\end{tabular}


Table 3. Savannah River Site Sample Collection Locations And Results Collection Dates: 15 - 16 July 1993

\begin{tabular}{|c|c|c|c|c|c|c|c|}
\hline $\begin{array}{c}\text { Sampling } \\
\text { Site }\end{array}$ & pH & $\begin{array}{l}\text { conduct. } \\
\mathrm{mS}\end{array}$ & $\begin{array}{l}\text { temp. } \\
{ }^{\circ} \mathrm{C}\end{array}$ & $\begin{array}{l}{ }^{3} \mathbf{H} \\
\mathrm{Bq} / \mathrm{ml}\end{array}$ & $\begin{array}{l}{ }^{129} \mathrm{I} \\
\mathrm{Bq} / \mathrm{mL}\end{array}$ & $\begin{array}{l}\text { RSD } \\
\%\end{array}$ & $\begin{array}{l}{ }^{99} \mathrm{Tc} \\
\mathrm{Bq} / \mathrm{L}\end{array}$ \\
\hline 1 & 6.08 & 0.012 & 23.4 & 0.017 & 0.001 & 101 & 0.010 \\
\hline 1 & 6.08 & 0.012 & 23.4 & 0.022 & 0.003 & 74 & 0.011 \\
\hline 2 & 6.32 & 0.032 & 27.6 & 0.058 & 0.015 & 65 & 0.020 \\
\hline 3 & 6.04 & 0.021 & 24.2 & 0.045 & 0.006 & 60 & 0.017 \\
\hline 4 & 5.96 & 0.011 & 21.7 & 0.036 & 0.019 & 47 & 0.015 \\
\hline 5 & 5.66 & 0.011 & 22.1 & 0.014 & 0.009 & 58 & 0.020 \\
\hline 6 & 6.29 & 0.042 & 22.9 & 0.034 & 0.005 & 104 & 0.017 \\
\hline 7 & 6.69 & 0.108 & 22.0 & 0.039 & 0.006 & 109 & 0.014 \\
\hline 8 & 5.59 & 0.015 & 23.2 & 0.038 & 0.003 & 115 & 0.015 \\
\hline 9 & 6.08 & 0.022 & 23.6 & 0.051 & 0.005 & 22 & 0.021 \\
\hline 10 & 6.23 & 0.018 & 23.7 & 0.053 & 0.009 & 60 & 0.020 \\
\hline 11 & 6.46 & 0.078 & 26.2 & 0.154 & 0.016 & 102 & 0.013 \\
\hline 12 & 6.39 & 0.026 & 32.1 & 0.108 & 0.004 & 103 & 0.030 \\
\hline 13 & 6.84 & 0.093 & 27.1 & 3.229 & 0.010 & 27 & 0.030 \\
\hline 14 & 6.65 & 0.095 & 27.7 & 5.900 & 0.015 & 62 & 0.026 \\
\hline 15 & 6.49 & 0.069 & 24.9 & 26.754 & 0.043 & 19 & 0.030 \\
\hline 16 & 6.65 & 0.059 & 25.6 & 10.856 & 0.023 & 28 & 0.022 \\
\hline 17 & 6.83 & 0.060 & 25.1 & 0.067 & 0.002 & 72 & 0.011 \\
\hline 18 & 6.89 & 0.081 & 25.5 & 2.619 & 0.004 & 150 & 0.014 \\
\hline 19 & 7.40 & 0.076 & 27.6 & 2.427 & 0.005 & 102 & 0.016 \\
\hline 20 & 6.89 & 0.093 & 25.9 & 2.761 & 0.023 & 14 & 0.016 \\
\hline 22 & 7.19 & 0.060 & 29.3 & 0.218 & 0.009 & 101 & 0.016 \\
\hline 23 & 6.91 & 0.061 & 28.5 & 0.225 & 0.009 & 55 & 0.025 \\
\hline 24 & 6.24 & 0.017 & 29.6 & 0.093 & 0.007 & 94 & 0.014 \\
\hline 25 & 6.73 & 0.073 & 28.8 & 0.056 & 0.002 & 46 & 0.013 \\
\hline 27 & 7.01 & 0.044 & 27.7 & 0.065 & 0.004 & 89 & 0.014 \\
\hline 28 & 7.16 & 0.044 & 25.3 & 0.053 & 0.007 & 104 & 0.012 \\
\hline 29 & 7.31 & 0.108 & 25.3 & 0.035 & 0.005 & 103 & 0.013 \\
\hline
\end{tabular}


Table 4. Savannah River Site Sample Collection Locations And Results Collection Dates: 7 - 9 February 1994

\begin{tabular}{|c|c|c|c|c|c|c|c|c|}
\hline Sampling & pH & condu & temp. & $\mathbf{3}_{\mathbf{H}}$ & ${ }^{129}$ I & RSD & ${ }^{99} \mathrm{Tc}$ & RSD \\
\hline Site & & $\mathbf{m S}$ & ${ }^{\circ} \mathrm{C}$ & $\mathrm{Bq} / \mathrm{ml}$ & $\mathrm{Bq} / \mathbf{m L}$ & $\%$ & $B q / L$ & $\%$ \\
\hline 1 & 7.61 & 0.015 & 13.9 & 0.057 & 0.078 & 37 & 0.013 & 23 \\
\hline 2 & 8.38 & 0.027 & 16.5 & 0.011 & 0.061 & 57 & 0.023 & 71 \\
\hline 3 & 7.61 & 0.020 & 15.3 & 0.021 & 0.065 & 40 & 0.009 & 56 \\
\hline 4 & 7.40 & 0.012 & 15.9 & 0.021 & 0.031 & 43 & 0.006 & 64 \\
\hline 5 & 7.45 & 0.013 & 16.0 & 0.015 & 0.026 & 44 & 0.009 & 55 \\
\hline 6 & 8.34 & 0.016 & 14.3 & 0.023 & 0.054 & 38 & 0.006 & 54 \\
\hline 7 & 8.05 & 0.112 & 15.2 & 0.025 & 0.086 & 36 & 0.021 & 49 \\
\hline 8 & 8.20 & 0.017 & 14.6 & 0.052 & 0.040 & 47 & 0.008 & 60 \\
\hline 9 & 7.55 & 0.019 & 12.8 & 0.272 & 0.049 & 37 & 0.010 & 24 \\
\hline 10 & 7.61 & 0.020 & 14.4 & 0.075 & 0.109 & 32 & 0.012 & 42 \\
\hline 11 & 7.37 & 0.042 & 16.0 & 0.134 & 0.013 & 20 & 0.010 & 45 \\
\hline 12 & 7.15 & 0.024 & 16.7 & 0.112 & 0.045 & 46 & 0.008 & 21 \\
\hline 13 & 7.88 & 0.049 & 18.0 & 4.440 & 0.025 & 48 & 0.015 & 39 \\
\hline 14 & 7.81 & 0.065 & 18.1 & 5.283 & 0.023 & 73 & 0.017 & 27 \\
\hline 15 & 7.82 & 0.065 & 14.9 & 16.951 & 0.081 & 30 & 0.023 & 12 \\
\hline 16 & 7.83 & 0.055 & 11.7 & 9.071 & 0.032 & 40 & 0.013 & 47 \\
\hline 17 & 7.95 & 0.038 & 12.8 & 0.006 & 0.057 & 61 & 0.007 & 52 \\
\hline 18 & 8.20 & 0.083 & 11.8 & 1.684 & 0.037 & 77 & 0.030 & 41 \\
\hline 19 & 7.95 & 0.069 & 10.5 & 1.626 & 0.119 & 57 & 0.026 & 31 \\
\hline 20 & 8.36 & 0.060 & 13.2 & 0.021 & 0.027 & 36 & 0.025 & 80 \\
\hline 22 & 8.15 & 0.066 & 9.8 & 0.238 & 0.028 & 58 & 0.012 & 45 \\
\hline 23 & 8.07 & 00.67 & 9.4 & 0.230 & 0.029 & 39 & 0.013 & 116 \\
\hline 24 & 8.92 & 0.015 & 12.8 & 0.065 & 0.064 & 35 & 0.013 & 78 \\
\hline 25 & 8.65 & 0.067 & 13.0 & 0.047 & 0.060 & 46 & 0.021 & 32 \\
\hline 26 & 8.13 & 0.050 & 9.5 & 0.097 & 0.099 & 40 & 0.012 & 34 \\
\hline 27 & 8.28 & 0.050 & 10.4 & 0.051 & 0.029 & 24 & 0.013 & 41 \\
\hline 28 & 8.15 & 0.059 & 10.4 & 0.039 & 0.054 & 39 & 0.009 & 14 \\
\hline 29 & 9.00 & 0.055 & 10.9 & 0.006 & 0.044 & 54 & 0.008 & 10 \\
\hline
\end{tabular}


Table 5. Savannah River Site Sample Collection Locations And Results Collection Dates: 6 - 7 June 1994

\begin{tabular}{|c|c|c|c|c|c|c|c|c|}
\hline $\begin{array}{l}\text { Sampling } \\
\text { Site }\end{array}$ & pH & $\begin{array}{l}\text { conduct. } \\
\text { mS }\end{array}$ & $\begin{array}{l}\text { temp. } \\
{ }^{\circ} \mathrm{C}\end{array}$ & $\begin{array}{l}{ }_{\mathbf{B q}}^{\mathbf{3}} \mathbf{\mathrm { m }} \\
\end{array}$ & $\begin{array}{l}{ }^{129} \mathrm{I} \\
\mathrm{B} \mathbf{q} / \mathbf{m L}\end{array}$ & $\begin{array}{l}\text { RSD } \\
\%\end{array}$ & $\begin{array}{l}{ }^{99} \mathrm{Tc} \\
\mathrm{Bq} / \mathrm{L}\end{array}$ & $\begin{array}{l}\text { RSD } \\
\%\end{array}$ \\
\hline 1 & 6.78 & 0.012 & 22.2 & 0.015 & 0.014 & 34 & 0.003 & 53 \\
\hline 2 & 7.55 & 0.033 & 25.5 & 0.027 & 0.014 & 7 & 0.004 & 11 \\
\hline 3 & 7.45 & 0.022 & 22.5 & 0.022 & 0.002 & 47 & 0.005 & 17 \\
\hline 4 & 7.30 & 0.010 & 21.0 & 0.022 & 0.010 & 52 & 0.004 & 19 \\
\hline 5 & 7.18 & 0.011 & 21.3 & 0.018 & 0.021 & 28 & 0.008 & 4 \\
\hline 6 & 7.57 & 0.015 & 21.8 & 0.072 & 0.023 & 52 & 0.010 & 130 \\
\hline 7 & 7.85 & 0.057 & 21.6 & 0.035 & 0.019 & 26 & 0.007 & 33 \\
\hline 8 & 7.41 & 0.016 & 21.9 & 0.043 & 0.010 & 48 & 0.011 & 69 \\
\hline 9 & 7.23 & 0.025 & 22.1 & 0.179 & 0.008 & 48 & 0.004 & 2 \\
\hline 10 & 7.31 & 0.018 & 22.4 & 0.385 & 0.014 & 28 & 0.003 & 4 \\
\hline 11 & 7.01 & 0.032 & 25.7 & 0.073 & 0.026 & 24 & 0.006 & 1 \\
\hline 12 & 7.34 & 0.023 & 25.2 & 0.100 & 0.017 & 28 & 0.004 & 6 \\
\hline 13 & 7.17 & 0.047 & 24.5 & 0.693 & 0.032 & 30 & 0.011 & 19 \\
\hline 14 & 6.99 & 0.061 & 24.8 & 3.041 & 0.019 & 48 & 0.018 & 63 \\
\hline 15 & 7.50 & 0.057 & 24.1 & 10.813 & 0.036 & 35 & 0.022 & 6 \\
\hline 16 & 7.59 & 0.041 & 23.1 & 10.383 & 0.025 & 24 & 0.028 & 23 \\
\hline 17 & 7.74 & 0.045 & 23.3 & 0.053 & 0.026 & 17 & 0.007 & 38 \\
\hline 18 & 7.88 & 0.097 & 24.4 & 1.877 & 0.019 & 40 & 0.004 & 62 \\
\hline 19 & 7.80 & 0.084 & 23.0 & 1.795 & 0.011 & 17 & 0.004 & 29 \\
\hline 20 & 7.98 & 0.097 & 24.3 & 0.122 & 0.019 & 20 & 0.021 & 116 \\
\hline 21 & 7.95 & 0.072 & 27.1 & 0.309 & 0.009 & 56 & 0.005 & 10 \\
\hline 22 & 7.99 & 0.070 & 25.3 & 0.260 & 0.026 & 42 & 0.011 & 89 \\
\hline 23 & 7.86 & 0.071 & 24.7 & 0.259 & 0.052 & 23 & 0.005 & 28 \\
\hline 24 & 7.67 & 0.016 & 27.1 & 0.098 & 0.005 & 37 & 0.003 & 9 \\
\hline 25 & 7.85 & 0.090 & 26.1 & 0.022 & 0.027 & 40 & 0.004 & 17 \\
\hline 26 & 7.78 & 0.050 & 24.1 & 0.058 & 0.062 & 20 & 0.003 & 28 \\
\hline 27 & 7.80 & 0.053 & 24.0 & 0.059 & 0.070 & 3 & 0.005 & 38 \\
\hline 28 & 7.89 & 0.069 & 22.8 & 0.036 & 0.007 & 59 & 0.005 & 58 \\
\hline 29 & 7.82 & 0.077 & 22.9 & 0.029 & 0.021 & 55 & 0.004 & 47 \\
\hline
\end{tabular}

